\title{
The reordering of the Batswana Cosmology in the 1840 English-Setswana New Testament
}

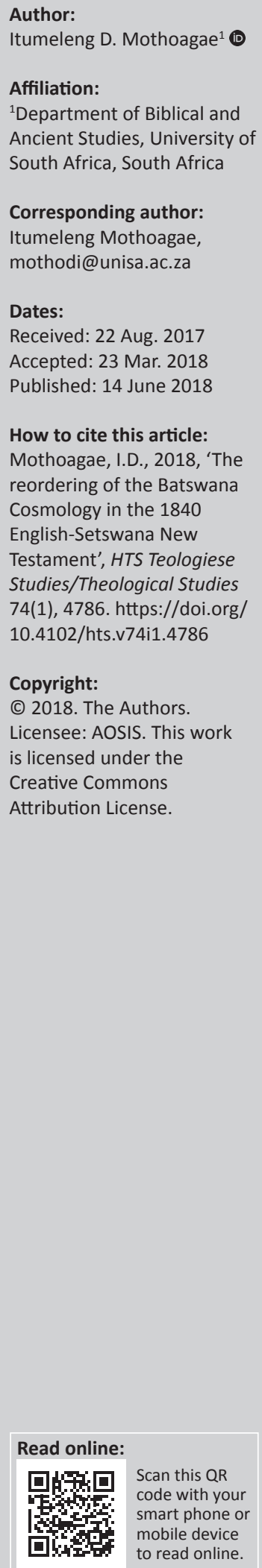

\begin{abstract}
Ngwao ya Setswana [tradition and customs] has two dimensions: tumelo [belief system] and thuto [education]; it is found in cultural practices and observances such as bogwera [the rite of initiation], letsemma [ploughing], dikgafela [harvesting], bongaka [diviner-healers] and botsetsi ba ntlha le botsetsi jwa bobedi [first menses and first experience of childbirth] to name but a few. These practices were observed through the slaughtering of animals, usually cows, and sheep and were condemned and regarded by missionaries as hindrances to Christianity. Letters to Mahoko a Becwana, a 1883-1896 newspaper, points to the use of biblical scriptures such as 1 Corinthians 10:1-33 by the missionaries to condemn these practices. The 1840 EnglishSetswana New Testament is a colonial product. Texts such as 1 Corinthians 10:21-22 point to the discursive practice employed by the translator for the purpose of foreignising Setswana cultural concepts, re-domesticating these cultural concepts as new concepts separate from their original meaning and domesticating anglicised concepts. At the centre of the discursive practice, I would argue, are foreignisation, redomestication and domestication. This version of the Bible depicts the impact of colonialism on the cultural practices of the Batswana. The debates in the letters to Mahoko a Becwana, point to the dichotomy of those Batswana who converted to Western colonial Christianity. The debates further depict the choices made by the Batswana when accepting the Christian practices expressed in Western culture, and renouncing all that made them a Motswana. The argument in this article is that in his translation of the Bible into Setswana, Moffat uses ideological strategy as a discursive tool to foreignise and redomesticate the concept of Badimo as a Badimoni [devil] and to domesticate the Western colonial Christian concept of heathen into Setswana vocabulary as baeteni, thus producing a dichotomy within the Batswana. Decolonial and post-colonial translation theories are used as the theoretical framework for this article.
\end{abstract}

\section{Introduction}

The name Moffat has an important place in the history of Bible translation. He is associated with the first complete Bible translated into Setswana. That history can be traced to 1825, when he translated a catechism along with John 3 and other passages of scripture into Setlhaping, a Setswana dialect of the Batlhaping people of the Dithakong area (Moffat 1842a:444). In 1825, the first-ever set of translations in Setswana was sent to Cape Town for printing. The London Missionary Society published it in 1826 (Coldham 1966:694). However, Moffat's translation work was interrupted significantly by fundamental changes made to these texts later on at the Kuruman mission. The next publication was the book of Luke in 1830. In 1840, the British and Foreign Bible Society published the complete New Testament in Setswana. A year later, the New Testament with Psalms followed. Finally, the whole Bible was completed and published in 1857 (Hermanson 2002:13). It is within this context that the translation of the Bible into Setswana emerges. This article presents the transmogrification of Badimo [ancestors] in the translation of the Bible. Moffat's first work begins with the representation of (di)ngaka [diviner-healer(s)] as agents of darkness or servants of Satan. Furthermore, Moffat's work seeks to undermine the role of these diviner-healers within the tribe of Batlhaping. This violates and subverts the spiritual spaces occupied by dingaka in the life of the community. In the present article, I follow Mojola's analytical approach. Mojola (2004) states:

postcolonial approaches to translation ... are primarily concerned with the links between translation and empire or translation and power as well as the role of translation in processes of cultural domination and subordination, colonisation and decolonisation, indoctrination and control and the ... hybridisation and creolisation of cultures and languages. (p. 101)

The text 1 Corinthians 10:21-22 in the 1840 New Testament, and subsequently in the 1857 Moffat Bible, serves as an illustration of the transmogrification and importation of a concept with spiritual and cultural significance. This concept in the target language became separated from its religious landscape and social constructs. Readers' letters to Mahoko a Becwana [Words of Batswana] during 
1883-1896 illustrate the effects of the transmutation of the concept of Badimo. The divide in those letters is evident. The association of Badimo with satanic practices in the text and in the letters is evident. The diviner-healer(s) played a significant role in the religious practices of the Batswana. The importing of Badimo, as a concept embedded within the Setswana religious landscape and with social significance, into a biblical text such as 1 Corinthians 10:20-21, among others, was to alienate the religious practices and belief in Badimo from the lived experience of the Batswana. This importing did not only subvert the function of the concept in terms of its physical, psychological and conceptual significance but also became a discursive tool that created a dichotomy between those practising their religious beliefs and those who 'converted' to Western colonial Christianity. Such a dichotomisation, I would argue, is evident in the cultural domination and subordination, colonisation, indoctrination and control of another culture and language. The text further domesticates a Western concept and renders foreign the concept of Badimo by renaming it as devils. In this article I do not seek to do an exegesis of 1 Corinthians 10:21-22 of the 1840 English-Setswana New Testament as translated by Robert Moffat, but rather I attempt to embark on an ideological critique within the theoretical paradigm of translation studies and decolonial theory.

\section{Perceptions about Setswana culture by the missionaries}

The evangelists' perceptions about Batswana culture emanated from their ideologies about the Batswana. Various journals, letters and books written in the late 19th century by missionaries illustrate the 'European' view about South Africa. These missionary accounts became an established European genre, as they took their place beside popular travel and exploration writings (Pratt 1985:119-143). The creation of such imperial literature was a form of creating a colonising discourse, which excited the Western imagination with glimpses of radical otherness brought under intellectual control. An example of such literature is apparent in Moffat's book of 1843 dedicated to the Queen, which asserts the following:

Philosophy must eventually confess her impotence; the pride of Science be humbled; and the fact be universally acknowledged, that the Gospel of Christ is the only instrument which can civilize and save all kindreds and nations of the earth. This has been verified by the labours of Missionaries in South Africa, and we have only to publish it through the length and breadth of that great Continent, in order to elevate and cheer its degraded and sorrowing inhabitants, and introduce them to the fellowship of civilized Nations. (p. iii)

The citation above indicates the type of literature generated by the evangelist about the so-called discovered people, who had no sense of right and wrong. It is within the context of the early 19th century that we need to understand the perceptions of missionaries about the Batswana. To understand the role of the evangelists, it is essential to locate their role within the broader project of colonialism. This is because the evangelists were also vanguards of British colonialism. According to them, the African interior presented itself as a virgin territory to be broken and a landscape to be invested with history (Comaroff \& Comaroff 1988:6). To various missionary societies' imagination, it was not only a matter of taking hold of the land but essentially seizing the hearts and minds of the so-called wild populaces. Secondly, it meant stimulating them from a state of nature that reduced them as indistinguishable from their rude surroundings. The description of the interior landscape as an agricultural metaphor can be seen in the way the missionaries such as Robert Moffat used the language to implant the perception of an 'uncivilised', 'virgin land' in the imagination of their audience. This is evident in Moffat's 1842 book, which states the following regarding the categorisation of the Batswana in the mind of the evangelists:

These missionaries went to the country of the Bechuanas, in South Africa. It was a hot and thirsty country, and the people were dark-looking, and wild, and filthy, and savage. (p. 8)

I would argue that the reception of Christianity among the Batswana was not based on the concept of equality, but rather everything that was African was categorised as idolatry, heathenism and satanic. This meant that to be a Christian, one had to abandon one's own identity and embrace a foreign identity. Mackenzie (Dachs 1975) refers to this as an act of civilisation. The following points to this effect:

The Bible often speaks to us about 'a dry and thirsty land, where no water is'. In such a land, of course, there can be no trees, or grass, or flowers. The ground is all dust and sand, affording neither shade nor food. Both men and animals must die of hunger or thirst. But if Rivers of Water could be turned into this 'dry and thirsty land', the wilderness would soon begin to 'blossom like a rose'. (p. 6)

The use of biblical imagery is evident in the above citation. Not only does the author refer to such imagery to paint a particular picture of the landscape and its inhabitants, but the idea is also an attempt to create what Wynter (2003) refers to as:

Processes made possible only on the basis of the dynamics of a coloniser/colonised relation that the West was to discursively constitute and empirically institutionalise on the islands of the Caribbean and, later, on the mainlands of the Americas. (p. 264)

\section{Moffat (1863) states the following regarding the Batswana:}

Nothing is wanted but water to change the desert into a fruitful field or a beautiful garden. The poor, ignorant people of South Africa had been for many ages like a barren wilderness. Children in this happy Christian land can have little idea of the misery and wretchedness of those poor heathens. They little know how much they have to be thankful for. This book is written to tell them something about the poor Hottentots, and Bushmen, and Bechuanas. They will soon find that the labours of missionaries among them have been like Rivers of Water in a dry place. (p. 3)

The description above can be summarised by the words of Quijano (2000). Quijano argues that the construction and categorisation of Africans were an invention constructed 
purely to enable the now globally expanding West. Western people intended to replace the earlier mortal or immortal, natural or supernatural, humans or ancestors, and the gods or God distinction as the one on whose basis all human groups had millennially 'grounded' their descriptive or prescriptive statements of what it is to be human, and to reground its secularising own on a newly projected human/ subhuman distinction instead (Wynter 2003:264).

Comaroff and Comaroff (1988) state that missionaries used garden metaphors as a way of cultivating a particular selfconsciousness. Therefore, in the missionaries' minds this would result in the 'savage' coming to a recognition of his or her true reflection. To put it differently, the missionaries thought that if this civilisation were to take place, the African would see himself or herself as a naughty child of God. In that regard, for the African to do God's will, it would mean he or she would need to be converted, to give up that which makes him or her distinct from other people as a Motswana (p. 6). Additionally, Comaroff and Comaroff observe (1988):

The naturalism that pervaded this discourse masked the coerciveness of colonialism and the part of Christian evangelism within it. For the European was to labour hard to displace the savage world, to clear away the 'mists' that clouded the native eye. Yet, despite his metaphors of mastery, his sense of himself as a bearer of eternal truths, the missionary was to be caught up in a reciprocal process. Bent on realizing a pious fantasy in the African wilderness. He had eventually to come to terms with the disconcerting image of himself that the wilderness gave back as the savage saw through the looking-glass, and reacted to the dangers lurking behind it. (p. 6)

The above observation points to some of the perceptions the missionaries had about the Batswana at the arrival of Christianity. This does not suggest that these perceptions ceased to exist once there were converts among the Batswana. This is seen in Moffat's attitude towards the Batswana in general, as he was essentially evangelical, holding that the missionary's primary task was 'to teach poor heathen to know the Saviour'. He considered other interests, however praiseworthy and irrelevant. He remained ignorant of African beliefs and traditional customs throughout his ministry. Furthermore, he indiscriminately condemned them all as vicious and perverted nonsense. It is for this reason that Moffat saw the Batswana as ignorant and godless. For him there was only hope for them under the hand of a gardenerfarmer. The gardener-farmer would cultivate their parched souls into the fertile fields of salvation. Moffat (1842a) further asserts:

Satan is obviously the author of polytheism of other nations, he has employed his agency with fatal success in erasing every vestige of religious impression from the mind of Bechuana (my own italics), Hottentots and Bushmen, leaving them without a single link to unite them to the skies. Thus the missionary could not make appeal to legends, or altars, or to an unknown God or to ideas kindred, to those he wished to import...Their religious system like those streams in the wilderness, which lose themselves in the sand had entirely disappeared, and devolved on the missionary to prepare for the gracious distribution of the waters of salvation in that desert soil, sowing the seed of the word, breathing many prayers, and shedding many a tear, till the Spirit of God should cause it to vegetate, and yield fruits of righteousness. (p. 244)

The description of the Batswana by Moffat is one of many indications of his preconceived ideas about Batswana people. He claims that they did not possess the same figures and race colour as those of European descent. The assertion by Moffat that Satan is the author of the Setswana religio-cultural practices, not only does he link Batswana with heathenism. $\mathrm{He}$ is also othering Batswana into the zone of none-beings. Secondly, the use of the name Satan not only was to categorise the Batswana as heathens but it was also to suggest that they are labelled as such because they were now evaluated and authenticated by the European eye. According to Moffat, anything not evaluated by the European eye lacked the capacity to be salvific and labelled as religious. It is for this reason that the categorisation of the Batswana cosmology as satanic came into being. Wynter (2003) citing Foucault refers to this as the 'invention of Man' (Wynter 2003:264). Wynter's description can be evidenced by the assertion made by John Moffat in the following manner:

When he went to South Africa in 1817, he found tribes of idolaters and savages, constantly at war with each other and with the white men, utterly ignorant and degraded. When he left it in 1870, churches had been called into existence, a permanent body of native pastors had been reared from among the Bechwanas, and the whole region had become largely civilised and Christianised. (Moffat 1885:iii-iv)

The categorisation of Batswana as idolaters and savages feeds into the discursive practice of Moffat. The ultimate strategy is to Christianise them; such a process will make Batswana in the eyes of the missionaries 'human' in terms of the Western Christian norms, in the process find salvation in Western Christianity. His discursive practice is also imperialistic in character identified in his description of the Batswana. He states:

Now I will tell you what kind of people the Bechuanas were, and a few of the things which missionaries had to put up with. And, first, you cannot think how dirty they were...they liked better to smear themselves with grease and ochre. Sometimes these poor dirty creatures would crowd into Mr Moffat's house while he was away, and Mrs. Moffat did not dare to ask them to go, or they might have stoned her in their rage. They would dirty everything they touched, and make the house hardly bearable. (Moffat 1842a:11)

The imperialistic characterisation of Batswana as dirty creatures and savages signifies the approach and perception of Moffat towards Batswana. These are racial and geographical markers suggesting that the presence of the missionaries in Africa is not in vain. In the eyes of the missionaries, it was actually justifiable to label Batswana as such, as they did not according to the missionaries check all the boxes that necessitated the 'declaration of them' as being fully 'evolved humans'. This is a form of 'othering' as they are first creatures, suggesting that they are soulless. The geographical location of Batswana speaks volumes, as they are located within the 
discourse of the discovered; their existence is measured and determined within the discourse of discovery. As 'creatures' Batswana cannot be equal and created in the image of God. ${ }^{1}$ Concisely, they are not children of God. Their 'animal-nature', which is labelled as 'savage' can be transformed by taking on Western Christianity. This could perhaps be one of the reasons why converts were compelled to take Western names and to abandon African names. As these names carried in themselves elements and characters of animal behaviour, this perhaps signified letting go of 'savage' creature-like practices to attain salvation. For them to 'qualify' they will have to take on the new religion and its norms. Robert and Mary Moffat (Moffat \& Moffat 1951) state the following regarding the Batswana religion:

Apart from their use of magic. The Ba Tswana had a welldeveloped system of religion. The dominant cult was the worship of ancestral spirits (Badimo). Each family was held to be under the supernatural guidance and protection of its deceased ancestors in the male line, to whom sacrifices were offered and prayers said on all occasions of domestic importance. (Moffat \& Moffat 1951:xxi)

To be sure, their impact lay as much in their depiction of the procedure as in the activities of its 'partakers'. To those who cared to listen, they told a story of an Africa slowly awakening to white initiative, as described by the Comaroff and Comaroff (1988:7). Yet the natives were no less historical performers, even though their actions might have retreated in the shadow of European self-representation. The encounter between the missionaries and the Batswana can be summarised as an encounter as much poetic as realistic. It is the exchange and misconception that set the terms and conditions for the long process of colonisation that was to follow.

The categorisation of the religious expressions of the Batswana by Moffat points to what Wynter (2003) describes as the 'coloniality of Power'. The argument by Wynter emerges from her analysis of Walter Mignolo, who asserts:

'Race' was therefore to be, in effect, the nonsupernatural but no less extrahuman ground (in the reoccupied place of the traditional ancestors/gods, God, ground) of the answer that the secularising West would now give to the Heideggerian question as to the who, and the what we are. (Wynter 2003:264)

\section{Wynter states:}

In the imaginary of the modern/colonial world system sustainable knowledge ... disregarded Amerindian ways of knowing and knowledge production that were reduced to curious practices of strange people and, in another domain were demonised. (p. 264)

This is what differentiated the reports of missionaries from more self-obliterating travel narratives. The missionaries' reports were their personalised heroic form as soldiers of the spiritual empire; in other words, their biographies illustrated some form of metaphoric realism of battles with the forces 1.The term "God" here is used in relation to the Judaea-Christian concept of Modimo. of 'darkness'. It is for this reason that the transmogrification, reordering and rewriting of Badimo [ancestors], religious rites as forces of darkness in the translated texts led to the marginalisation and disruption of the Batswana cosmological belief system. The text did not only do that, however; rather, it became a tool to replace, subvert and colonise the Batswana cosmology and culture. Such an act of hybridisation and creolisation takes place through the ordering of the Batswana cosmology and culture and the linking of individual achievement to the conquests of civilisation.

The attitude of Moffat could be summarised in what Mbembe refers to as 'Image Ontology' (Mbembe 2014). The encounter between the missionaries and the Batswana can be traced most accessibly in letters, reports, journals and published works. These documents recollect the self-awareness journey to the mission field. Nevertheless, there is also a palpable Setswana observation of these happenings, spoken less in the narrative voice than in the symbolism of gesture, action and reaction and in the expressive manipulation of language. The interplay, of course, was between two parties of disproportionate power, reflected in the fact that the evangelists were extremely aware of their ability to 'make' history.

\section{Translation as a political project}

The 1840 English-Setswana New Testament Bible emerges within the broader Bible narrative of the Western world during the 19th century, as well as the prolific production of knowledge regarding its origins, its problems and meanings. Already before the end of the 17th century, an explosion of Bible translations took place, subsiding towards the end of that century, reflecting a 'religious textual stabilisation' allowing for its position of status within emerging nationalisms (Sheehan 2005:17). The European origins of what can be called the vernacular Bible would also have an impact, along with the processes of colonisation that had already commenced at this stage. The assessment by Sheehan (2005) points to the political nature of translation. Similarly, Mojola reminds us that there is an intrinsic link between translation and empire, translation and power and domination, subordination, colonisation and decolonisation. The 1840 English-Setswana Bible was aimed at communicating and implanting Western colonial thought.

The historiography of the Church in South Africa asserts that the arrival of evangelists in the country epitomised the advent of literacy among Batswana people. The vernacularisation of the Bible into Setswana meant transformation and conversion of the Batswana into 'civilised humans'. The evangelists promoted Christianity, rather than authenticating and preserving Setswana culture and tradition. As pointed out in the previous section, this is confirmed by Moffat's incapability to understand the manners and customs of Bechuanas (Batswana), despite spending decades among the Batswana people and learning their language by the 'immersion method' (Moffat 1842a:249). 
Schapera in the volume he edited of the letters and journals of Robert and Mary Moffat, (1951) argues that Moffat remained ignorant of Batswana beliefs and traditional customs throughout his ministry, condemning them all indiscriminately as vicious and perverted nonsense (Moffat \& Moffat 1951:xxvii). Through his works, Moffat actualises and reinstates his colonial thought and trajectories within the subconscious of the target audience, thus creating what Du Bois (1903) refers to as double consciousness.

The 1840 translation of the New Testament into Setswana needs to be located within the context and time of Robert Moffat. It did not take place in a vacuum. The translation project became a literary vehicle used by Moffat to marginalise Setswana cosmology, including racialisation and gendering of Modimo. It is in the making of such literature that an exercise of manipulation, alteration, rewriting and cultural translation to serve the particular purpose of evangelisation is performed (Arduini \& Nergaard 2011:8-15; Bassnett \& Lefevere 1990:1-13; Gentzler 2001:187-203).

The above assertion is seen in Moffat's submission on rituals performed by the Batswana. In his view, they seem to be similar to Mosaic laws from the Old Testament, further suggesting that they are 'like shells without the kernel'. Not only does he relegate and compare the rituals with those of the Mosaic laws, but he repeatedly states that he comes up against the sayings and acts of a so-called rainmaker, to whom the Batswana attached great value (Moffat 1842a: 263-266). The dismissal of Batswana cosmology emanates from what Dube (2014) identifies as the agenda to sell a different form of spirituality, which operates from a colonial framework that seeks to dismiss all other forms of spiritual knowledge. Dube (2014) further maintains that to achieve this, Moffat narrates his encounter and characterisation of the ngaka [diviner-healer]. Moffat's efforts to translate and remove the ngaka from the central social welfare figure among the Batswana to become an outright evil is an attempt to rewrite and transfer the concept of ngaka into a new meaning (Dube 2014:157). What Dube is arguing is the characterisation of the ngaka as an outright evil. The concept of ngaka cannot be separated from the role of the Badimo in the spirituality of the Batswana. At the centre of this categorisation is Moffat's discontent with the influence of and belief in the role of the ancestors in the life of the Batswana. The rewriting and the transmutation of the concept of ngaka from its intended meaning and role illustrate what Mojola (2004) refers to as the link between translation and empire and translation and power. Additionally, this is a clear attempt by Moffat to use translation as a discursive tool to attain cultural domination, subordination, colonisation, indoctrination, control and creolisation of cultures and languages. From this viewpoint, it can be argued that translation is viewed essentially as a tool of empire. Similarly, Robinson (1997) observes:

The study of translation and empire, or even of translation as empire was born in the mid-to-late 1980s out of the realization that translation has always been indispensable channel of imperial conquest and occupation; not only must the imperial conquerors find some effective way of communicating with their subjects; they must develop new ways of subjecting them, converting them into docile or 'cooperative' subjects. (p. 10)

After establishing himself in Kuruman in 1826, Moffat relied entirely on interpreters to communicate in Setswana and also still depended heavily on the Dutch. Through his journals, Moffat provides interesting pointers into the efforts that eventually produced his Setswana translations. He states that the process was a tough and tiresome one, as the time for interpretations and translations was usually at the end of a long day of manual labour. The gaining of the language was an object of first importance for Moffat. He suggests that he had to attain the language under the most unfavourable circumstances. As far as he was concerned, there was neither time nor place of retirement for study and no interpreter worthy of the name. Yet he depended a lot on these interpreters. Perhaps this is why he thought so little of them. He states:

A few, and but a few words were collected, and these very
incorrect, from the ignorance of the interpreter of the grammatical
structure either of his own or the Dutch language, through which
medium all our intercourse was carried on. It was something like
groping in the dark, and many were the ludicrous blunders
I made. The more waggish of those from whom I occasionally
obtained sentences and forms of speech, would richly enjoy the
fun, if they succeeded in leading me into egregious mistakes and
shameful blunders; but though I had to pay dear for my credulity,
I learned something. (Moffat 1842a:291)

The assertion by Moffat in the above citation point to the argument by Robinson (1997) that translation is neither apolitical nor ahistorical in the above statement. It is, therefore, evident that such a process was a political project from the very beginning. Similarly, in her article on translating ngaka [diviner-healer], Dube (2014) illustrates what Robinson refers to as the indispensable channel of conquest and occupation ... through translating ngaka as agents of darkness. Moffat advances new ways of subjecting the custodians of Setswana cosmology into the process of converting them into docile cooperative subjects and sees their religiosity as an enemy to be destroyed. This is seen in his translation of ngaka rather than the concept being portrayed as occupying a central and positive role in Setswana culture. It is relegated to a marginal position and even depicted as evil and an imposter.

\section{Translation and the colonisation project as two sides of the same coin}

Dube (2014) highlights the fervour of the missionaries who considered themselves bound to spread the word of their god. They acknowledged the significance of literacy in persuading the Batswana. This became a central tool in the method of reducing Setswana into a written language; literacy, through the translated text, became a technology of power. Post-colonial theorists are increasingly turning to translation and both re-appropriating and reassessing the term itself. For centuries, translation was perceived to a large extent to be a 
one-way process. The production of translated text in European languages (i.e. for European consumption) was vernacularised for non-European communities. As a result, European norms through vernacularisation have dominated literary production and have ensured that only certain kinds of text (i.e. those that will not prove alien to the receiving culture) come to be translated. It is for this reason that post-colonial theorists in their scrutiny of translation argue that there is a close relationship between colonisation and translation. As Dingwaney and Maier (1995) remind us, translation is often a form of violence.

Rafael (1988) illustrates the violent form of translation within the project of colonisation. Rafael (1988) labels different implications that translation had for the Spanish colonisers and the Tagalog people of the Philippines:

For the Spaniards, translation was always a matter of reducing the native language and culture to accessible objects for and subjects of divine and imperial intervention. For the Tagalogs, translation was a process less of internalizing colonial-Christian conventions than of evading their totalizing grip by repeatedly marking the differences between their language and interests and those of the Spaniards. (p. 213)

This pinpointing of different implications by Rafael can also be identified in the translation of the Bible into Setswana. The literature corpus of travellers, explorers and missionaries in Southern Africa illustrates Rafael's argument. Similarly, as Mojola and Wendland (2003) point out, the suggestion that translation has to do mainly with questions of textual equivalence or the faithfulness of the target text to the original source text has to be disputed. They argue that an axiom of the post-colonial approach is based on the point that translation has much to do with the 'micropolitics' of empire, and the promotion of the interests and well-being of empire. Thus, the periphery necessarily serves the interests of the imperial centre (Mojola \& Wendland 2003:22). The translation of the Bible, hymns and catechism into Setswana does nothing more than serve the interest of the imperial centre. It is in such literature that we are confronted with the first evidence of the promotion of the interest and well-being of empire. The translation of such material was to re-emphasise this colonial thought. This is done by reinstating Moffat's colonial thought and trajectories within the subconscious of the target audience, thus creating a double consciousness. Thus, through his project of the vernacularisation of the Bible, Moffat uses literature as an attempt to marginalise dingaka. ${ }^{2}$ This is also an exercise of manipulation, alteration, rewriting and cultural translation to serve the particular purpose of evangelisation (Arduini \& Nergaard 2011:8-15; Bassnett \& Lefevere 1990:1-13; Gentzler 2001:187-203).

Following the argument made by Dingwaney and Maier (1995) that translation is often a form of violence, the translation of the ngaka as an agent of evil, the decentralisation of Badimo from the religiosity of the Batswana and subsequently the vernacularisation of the Bible into Setswana were no accidents. Rather, the project was a form of violence to the tradition and customs of the Batswana. The translation introduced the Batswana to masculine expressions of Modimo, the dualism of the body as body and soul, goodness and evil, sin and death, judgement and punishment and life and eternity. These Western theological expressions were imported and domesticated into Batswana cosmology, thus producing a different kind of a Motswana - a colonised being. In his book, Moffat (1842a) devotes a whole chapter to ngaka. He acknowledges the influence of the ngaka in the public space. Moffat has the following to say about the ngaka:

In every heathen country the missionary finds to his sorrow, some barriers to his usefulness, which require to be overcome before he can expect to reach judgement of the populace. Sorcerers or rainmakers, for both offices are generally assumed by one individual, are the principal with whom he has to contend in the interior of Southern Africa. They are ... our invertebrate enemies, and uniformly oppose the introduction of Christianity among their countrymen to the utmost of their power ... they constitute the very pillars of Satan's Kingdom, in all places where such impostors are found. By them his (Satan's) throne is supported and the people kept in bondage. The rainmaker is in the estimate of the people no mean personage, possessing an influence over the minds of the people, superior even to that of their king, who is likewise compelled to yield to the dictates of this arch-official ... Each tribe has one and sometimes more. (p. 208)

The above citation points to the link between translation and colonialisation as two sides of the same coin. It reveals how image ontology influenced Moffat's outlook towards the Batswana. It also reveals the description of Moffat and his translation of the ngaka and Badimo as a form of foreignisation and redomestication. Similarly, he associates the dingaka with the realm of darkness, viewing them as agents of Satan who prevented the Batswana from accepting the 'word of God'. Moffat's view is further exacerbated by his attempt to domesticate the Judaeo-Christian concept of evil by identifying it with the diviner-healers. At the same time, he foreignises dingaka and Badimo. He imports the JudaeoChristian dualistic approach, which is contrary to the Batswana religious worldview. This is seen in the translation of sorcerers as dingaka. In doing so, Moffat does not even pretend to be faithful to the source culture but instead forms part of the project to 'overcome the barriers'. This constitutes a violent act of rewriting as the other form of imperial Western colonial Christian worldview.

Dube (2014) makes the following observation:

It was in this public capacity that dingaka tsa baroka were visible forces to missionaries and regarded as opponents of the Christian faith. They were seen to reinforce the recognition of badimo instead of the Christian God. Robert Moffat dedicates more than a chapter to dingaka tsa dinaka, specifically the moroka. It is a full narrative construction with leading, opposing and minor characters with a plot, setting and climax. (p. 160)

If translation was not an indispensable channel of imperial conquest and occupation, if the conquerors did not aim to 
use translation effectively to develop new ways of subjecting the conquered and converting them into docile subjects. It therefore begs the question: why did Moffat dedicate a full chapter to dingaka as agents of darkness? The argument by Dube (2014) I would contend that it points to the binary of how Moffat uses the text as a technology of power and secondly and how he uses technology as a tool to domesticate and foreignise Batswana people. He does this by rewriting the positive role fulfilled by the dingaka in their society as a negative one. Moffat does not only subjugate dingaka through the power of his pen, but he rewrites them as 'sorcerers', 'rainmakers' and 'impostors'. Additionally, he not only subjugate them as the impostors and as the pillars of Satan's kingdom, supporters of Satan's throne, who kept their communities in bondage (Dube 2014:218), but he portrays the community as foolish followers of Satan. In doing so, he undermines the role and centrality of the dingaka within the community. It is imperative to understand that Badimo communicated with the community through dingaka. By creating such a binary, Moffat uses a hegemonic outlook in his work to be the vehicle for subverting, replacing and colonising the space occupied by the dingaka and Badimo in the community.

Ntloedibe-Kuswani (2000) maintains that it is in Moffat's rewriting that we see a move from the idea of the divinerhealers, occupying a positive role and contributing to the well-being of Setswana society in relation to its members, the environment and the divine powers (p. 502). Similarly, Dube (2014) critically engages with the use of literature to destabilise and marginalise the dingaka:

Contemporary translation studies now highlight the power relations and ideological positions of the translator, publishers, target audiences, patrons, and other stakeholders that shape translations. (p. 158)

Power relations embedded in the process of translation became a technology of power. The missionaries, through literature, exercised these power relations. The outcome of this, I would argue, was the violation and the creation of a binary, namely the transmogrification of Setswana religious concepts and the marginalisation of the dingaka in the life of the community. I would further argue that this not only aggravated the relationship of the dingaka as the spiritual leaders of the community, but it also affected the role and function of Badimo as part of the divine role and of the dikgosi in the spirituality of the people. This further affected Badimo who function as unifiers, protectors, intercessors and custodians of the tradition and customs of the Batswana.

A Bible in Setswana was one form of literature which would be a vehicle in the process of altering the cosmological, political and economic meaning of the world of the Batswana. It is essential to view the alteration of the Batswana cosmological worldview both politically and economically. This is something that took place at various levels: the masculinising of Modimo (Mothoagae 2014:149-168;
Ntloedibe-Kuswani 2001:78-97), ${ }^{3}$ the relegation of Badimo ${ }^{4}$ [ancestors] and dingaka into the realm of evil and darkness, the dislocation of dikgosi as key intercessors between the community and the divine, the marginalisation of women in the economic, political and religious life of the community and family and the transmogrification of Batswana cosmology into the text.

Cheyfitz (1991) also argues along the same lines as Mojola and Wendland. He maintains that translation was 'the central act of European colonisation and imperialism in America' (p. 104). As a result, there is a need to recognise that colonialism and translation go hand in hand (Rafael 1988:213). The translation of the Bible into Setswana by Moffat cannot be separated from the intention of colonial thinking at the time. The English text points to the notion of civilising the so-called heathen. The translation of the Bible into Setswana by Moffat was an act of civilisation. The use of particular English words and the total reliance on the 1611 King James Bible illustrate the argument by Bassnett and Trivedi (1999):

The act of translation always involves more than language. Translations are always embedded in cultural and political systems, and in history. For too long translation was seen an aesthetic act, and ideological problems were disregarded. Yet the strategies employed by translators reflect the context [of power interest and values] in which texts are produced. (p. 6)

In his act of translating the Bible into Setswana, Moffat had to employ a particular strategy. That strategy was to choose which part of the Bible to translate first. From the onset he discursively positioned himself by starting with the New Testament Gospel of Luke and first and second letter of John. As Bassnett and Trivedi (1999) rightly point out, within the strategies used by the translator, context is crucial in identifying the power interests and values. As a missionary, Moffat does not pretend to appreciate the values expressed in the customs of the Batswana. On the contrary, he refers to these customs and practices as a hindrance to civilisation and conversion to Western colonial Christianity. The power interest also lies in the choice of texts he chose to translate for reasons known to him alone. The discursive choice and power interest could be drawn from his assertion that there are some similarities between the Mosaic law and the tradition of the Batswana. According to him, this necessitated the translation of the New Testament rather than the Old Testament. Furthermore, in his works we are confronted with the transmogrification of diviner-healers as agents of Satan and with the foreignisation of Badimo as evil spirits. Both in the translated biblical texts and in his works, he illustrates the extent to which translations are always rooted in discursive, cultural and political systems. 1 Corinthians 10:20-21 serves as an example of the strategies employed by Moffat and reflects

3.I have reservations in referring to Modimo as God, as the two are distinctly different The Setswana understanding of Modimo is gender neutral, while the Christian The Setswana understanding of Modimo is gender neutral, while the Christian understanding of God is a gendered one. It is on this basis that I intentionally refer
to Modimo rather than God.

4.In Setswana tradition and belief, the ancestors form part of the hierarchy of the divine, starting with Modimo in the heavens to the living parents of an individual. divine, starting with Modimo in the heavens to the living parents of an individual.
This means treating your parents with respect and honour was respecting Modimo, as they are the living ancestors. 
the context in which the 1840 English-Setswana New Testament was produced (Bassnett \& Trivedi 1999:6).

\section{Contextualities and definitions}

In this article, I attempt to engage critically with 1 Corinthians 10:20-21 from an ideological criticism stance within decoloniality theory and translation studies. The fundamental question is: why did Moffat transform demons into Badimoni and alter the belief in the Badimo as a form of a sacrifice to devils? Other questions can be asked, such as: what was the role of Badimo within the religiosity of the Batswana? What was the religious structure or hierarchy within the Batswana belief system? What was the understanding of the presence of Badimo in the life of the Batswana? Was there a link between various rituals and the divine? I have indicated in the preceding sections that in his writings Moffat shows no interest in the religious belief of the Batswana and their governance. Instead, he sees all of these as a hindrance to their conversion.

It is therefore within this context that decoloniality needs to be defined. Ndlovu-Gatsheni (2013) defines decoloniality in the following manner:

By decoloniality it is meant here the dismantling of relations of power and conceptions of knowledge that foment the reproduction of racial, gender, and geo-political hierarchies that came into being or found new and more powerful forms of expression in the modern/colonial world. (p. 14)

In analysing the translation of 1840 English-Setswana New Testament, it is imperative to recognise firstly that the text emerges from a particular period. It is in the translated text that we are confronted with the power relations between those subjected to the power of the pen and the scribe. This includes the Westernised (i.e. anglicised) names of characters and geographical locations in the Bible and foreignisation of cultural practices and knowledge systems. Translation has much more to do with the macropolitics of empire and the promotion of the interest and well-being of empire. Those subjected to the pen of the scribe serve the interest of the imperial centre. Put differently, losing sight of the impact of ideology, politics and economy in the process of vernacularising the Bible is to not recognise the interplay between power relations, conceptualisation of knowledge and the role these play in the reproduction of racial, gender and geopolitical hierarchies.

The translation of both the New Testament and the Old Testament into Setswana by Moffat becomes an extension of the discursive nuances that led to the translation of the Bible into English. As a source text, the 1611 King James Bible embodied the colonial imperial thought that necessitated the production of such a text. The use of Western expressions, numbers, names, geographical locations and the style of translating as found in the 1611 King James Bible is just another form of expressing the effects and intentions of such a project. These issues epitomise Christianity within the Batswana people as a religion that sought to replace, rewrite and manipulate the present with the foreign.
The 1611 King James translators where instructed to make their project a close revision of the Bishops' Bible, even though they would consult the Hebrew and Greek source texts (Metzger 2001:76). Similarly, Metzger (2001) argues that Moffat followed the 1611 King James literally. It is observable from all his translations starting with the 1830 Gospel of Luke, the $1840 \mathrm{New}$ Testament and the completion of the Bible in 1857 Moffat that strictly following the forms of source texts may have adverse results, such as ambiguity in communication and clumsiness in the target (receptor) language style. He avoids marginal notes altogether, supposing that notes 'would bring into question the authority of the scriptures' (Metzger 2001:73-74). However, the 1611 King James essentially had about 9000 margin references throughout the Bible (Metzger 2001:75). Muller (1958) points out that Moffat was not trained in Greek or Hebrew, so his Bible 'had not been translated from the original languages, but from the English version' (Muller 1958:2).

\section{Foreignisation, redomestication and domestication in 1 Corinthians 10:20-21}

The process of foreignisation, redomestication and domestication is a spiral process within the act of translation. The process, I would argue, does not necessary follow a particular format, it happens simultaneously depending on the text. Moffat's discursive strategy was to reduce first Setswana into a Western written language ${ }^{5}$ and secondly to evangelise, civilise and colonise not only Batswana but also their language. The citation below indicates that:

Satan is obviously the author of the polytheism of other nations; he has employed his agency, with fatal success, in erasing every vestige of religious impression from the minds of the Bechaunas, Hottentots, Bushmen; leaving them without a single ray to guide them from the dark and dread futurity, or a single link to unite them with the skies. (Moffat 1842a:244)

The above citation points to the discursive strategy that compelled Moffat to reduce Western colonial Christianity into Setswana. As far as he was concerned, Batswana had no knowledge of God. The knowledge of God in this instance is Western colonial God, a gendered white being. Moffat's discursive strategy was based on a particular perception about Batswana. The categorisation of Batswana as filthy and heathen was not only an act of 'Othering', rather points to the zeal to want to have Setswana Bible at the disposal of Batswana. The translation of the Bible facilitates Christianity to become a vehicle of imperialism and Western norms used to measure and distinguish between the 'uncivilised' and 'civilised'. The availability of the Christian literature will not only elevate Batswana from their filthiness but will also enable them to be children of the 'Western colonial God'. This is a move from being creatures, which on its own this concept suggests that they had no souls, as they are wild, savage and animal-like in their behaviour. Lastly, his discursive strategy to evangelise, civilise and colonise the Batswana was based on the perceptions that the Batswana were filthy, savage, animalistic, wild and dark-looking features that are generally

5.By western, I mean that he used western sentence construction. 
attributed to Satan in Christian literature. It is these suppositions that form the bedrock of Moffat's discursive strategy, and the Moffat Bible becomes a discursive tool in the process of foreignisation, redomestication and domestication in the reordering of the Batswana cosmology. It is in his book (1842a) and other works that we can identify these processes. The 1611 King James Bible was the source text for Moffat's translation. In it, 1 Corinthians 10:20-21 reads as follows:

20 But I say, that the things which the Gentiles sacrifice, they sacrifice to devils, and not to God: and I would not that ye should have fellowship with devils. 21 Ye cannot drink the cup of the Lord, and the cup of devils: ye cannot be partakers of the Lord's table, and of the table of devils. (author's own italics)

Moffat translates the text in the following way:

v.20 Mi ka re, Lilo tse Baeteni ba li shupeletseñ, ba li shupela go Badimoni, mi esiñ Morimoñ, mi kia gana gore lo abalane le Badimoni. V21 Ga lo kake loa noa senoèlosa Morèna, le senoèlo sa Badimoni: ga lo kake loan a baaberioi ba lomati loa boyèlo loa bademoni. (Bibela ea Boitsepho ee Cutseng Kholagano e Kholugolu le e Nca, tse ri Hetolecoeng mo Puon ea Sechuana:1840:323, [author's own italics])

The above translation signals the use of language as a technology of power in such a way that it creates a particular image in the mind of the reader as intended by the translator. Moffat, through language, employs a strategy that reflects the context in which the use of imperial hegemonic interests and values resides. The exorcism narratives in the gospels and texts, such as 1 Corinthians 10:20-21, are translated in a manner that seeks to demonise those that operated as intercessors, in this case dingaka and dikgosi and those that resided in the realm of the divine:

\section{King James Bible}

Verse 20: But I say, that the things which the Gentiles sacrifice, they sacrifice to devils, and not to God: and I would not that ye should have fellowship with devils.

In verse 20, Moffat domesticates a foreign word into the vocabulary of the Batswana. He translates the word Gentiles into baeteni. It is essential to point out that he uses an English word 'heathen' and domesticates it into a Setswana word. In so doing, Moffat reorders the word gentile to perform a particular act in the cosmology of Batswana. Thus, suggesting to the audience there is some of dualism within Western Christianity, namely, believers and non-believers. In the Batswana cosmology, he creates a binary between those converting to Christianity and those that clang to their cultural practices. The word baeteni does not only create a binary among Batswana but also forms a part of image ontology used to characterise the religiosity of the Batswana. The word also forms part of the imperial ideology that is aimed at making a distinction between themselves and the 'discovered' and 'uncivilised'. In the text, the word takes a different spin, as it further differentiates between those assimilated into Western colonial Christianity and those who continued to practise their religion. It is essential to place the word within this context, as it is context that gives words meaning. I would further argue that, in morphing the word into Setswana vocabulary, Moffat dehumanises nonEuropean cultures and traditions.

Moffat uses the incorrect words ba li shupeletseñ [pointing to or towards] instead of sa go etsa setlhabelo [to make sacrifice]. The transmogrification of shupeletseñ as implying sacrifice rather than using the correct word sethabelo is an act of altering meaning, as the word setlhabelo has a deeper meaning in Setswana. The word as part of the vocabulary signifies an offering given to the Badimo [ancestors] and Modimo. This word has religious significance; the avoidance of the use of the word and formulation of a totally new word that has nothing to do with sacrifice points to the domestication, manipulation of the text to fit the political, discursive ideological interest of the translator. The transmogrification of baeteni and shupeletseñ has a culture-specific function, namely, to transfer imperialist cultural memory and standards to Batswana readership.

He translates 'they sacrifice to devils' as ba li shupela go Badimoni. In translating devils as Badimoni, Moffat begins first by foreignising and alienating the concept of Badimo from its cosmological meaning. He redomesticates Badimo as devils. It is in the act of redomestication that the process of morphing the word Badimo into Badimoni. The foreignisation of Badimo is a discursive act was to reorder the spiritual concept in the belief in Badimo and uses it in the texts as meaning devils. This links with his belief that the Batswana had a superstitious belief in magic and Badimo. He inserts the suffix (ni) at the end of the word while retaining the root of the word. In other words, Moffat imports a concept that is associated with the religious belief system of the Batswana with the aim of foreignising that concept to Christianise the Batswana. It is in the morphing of the word that he not only rewrites and manipulates but further marginalises the most central belief of the Batswana:

\section{King James Bible}

21 Ye cannot drink the cup of the Lord, and the cup of devils: ye cannot be partakers of the Lord's table, and of the table of devils.
1840 English-Setswana New Testament

V21 Ga lo kake loa noa senoèlo sa Morèna, le senoèlo sa Badimoni: ga lo kake loana baaberioi ba lomati loa boyèlo loa bademoni.
In verse 21 Moffat translates 'cup of devils' as senoèlo sa Badimoni. Traditionally, to partake in the offering to the divine, a traditional beer is brewed. As someone who lived among the Batswana, Moffat was exposed to various rituals and celebrations such as dikgafela [harvesting]. According to Moffat, all these practices were a hindrance to the civilisation and conversion of the Batswana, and he thus transforms them into acts of Satanism and lacking in themselves the salvific element. Therefore, this subjects them to the pen of the translator as an act of violence, as alluded to previously. In the two verses, the word Badimo(ni) appears four times. 
In both tables of the translation above, we can clearly see the representation of heathen as baeteni and devils as Badimoni. It is here that we are confronted with the rewriting, manipulation and transformation of Setswana tradition as part of satanic practices. In doing so, Moffat not only domesticates baeteni and foreignises Badimo but also intentionally misrepresents the concept Badimo.

The above verses point to the foreignisation, redomestication and domestication of Batswana religious concepts. As they take on a new meaning in the text, they become redomesticated. They fulfil a particular role in the mind of the translator. Other than the exorcism narratives in the Gospels, another example of this is Luke 2:21. In his translation of the circumcision of Jesus, Moffat imports the religious concept of the Batswana bogwera as meaning circumcision. In doing so, he manipulates and appropriates such a concept to conform to his ideological strategy. In 1 Corinthians 10:20-21, Moffat uses the same strategy to manipulate the concepts of heathen and Badimo, and foreignises, redomesticates and domesticates them to give them a new meaning, separate from their original meaning.

The question is whether Batswana had a concept of evil. If they did, why not use the correct word for that. In the 1840 English-Setswana New Testament he translates the word 'demon/devil' as Badimoni as stated earlier. The word Badimoni appears for the first time in his translation. I would argue that the transmogrification of Badimo as Badimoni in 1 Corinthians 10:20-21 was aimed at producing a new meaning and communicating a particular ideology, and this was a form of reordering the cosmology of Batswana through the process foreignisation and redomestication. Thus, the 1840 and subsequently the 1857 English-Setswana Bible is a colonised text, ideologically separate from the original Hebrew and Greek texts and the 1611 King James Bible. Put differently, it has a life of its own. Additionally, the strategy to manipulate the Setswana cultural concept of Badimo as evil or demon and devil was to foreignise and redomesticate the concept in such a manner that Badimo became alienated, thus producing some form of cultural revolution or rather what Mackenzie (Dachs 1975) refers to as an act of civilisation. The question then follows: why did he transliterate the word 'demon' in the 1830 translation of the Gospel of Luke?

In so doing, Moffat seeks to reorder the political order, spiritual spaces and the Batswana cosmological worldview. These reordering, rewriting and appropriation are used ultimately to indoctrinate. Bassnett (in Gentzler 2001) reminds us:

Rewriting is manipulation, undertaken in the service of power, and in its positive aspect can help in the evolution of literature and a society. Rewritings can introduce new concepts, new genre, new devices, and the history of translation is the history also literary innovation, of the shaping power of one culture upon another. But rewriting can also repress innovation, distort, and contain ... (pp. 187-203)

The use of the word 'heathen' (baeteni) as a foreign word was to introduce a new concept and genre in what Bassnett (in Gentzler 2001) refers to as the shaping of power of one culture upon the other. The use of the concept of Badimo as devil is not only rewriting and manipulation, but it is also a repression of innovation and distortion of the positive aspects of the role of Badimo in the life of a household and the community. Venuti, cited in Mojola and Wendland (2003), emphasises that fluency in translation can involve not just a domesticating of language but also of ideas. This goes well beyond the issues of fidelity, historical and geographical situations that are often discussed in biblical literature:

Every step in the translation process from the selection of foreign texts to the implementation of translation strategies to the editing, reviewing, and reading of translations is mediated by the diverse cultural values that circulate in the target language always in some hierarchical order. The translator ... may submit to or resist dominant values in the target language with either course of action susceptible to ongoing redirection. Submission assumes an ideology of assimilation at work in the translation process, locating the same in the cultural other, pursuing a cultural narcissism that is imperialistic abroad and conservative, even reactionary, in maintaining canons at home. Resistance assumes an ideology of autonomy, locating the alien in a cultural other, pursuing cultural diversity, foregrounding the linguistic and cultural differences of the source language text and transforming the hierarchy of cultural values in the target language. Resistance too can be imperialistic abroad, appropriating foreign texts to serve its own cultural political interests at home, but insofar as it resists values that exclude certain texts, it performs an act of cultural restoration which aims to question and possibly re-form, or simply smash the idea of, domestic canons. (p. 21)

It is in translating devil(s) as Badimo(ni) in the text that Moffat installs another occupant in the spiritual spaces of the Western colonial Christian religion. The installing of the occupant is regarded as an alternative to tradition and its cosmological worldview. The text then becomes a tool to subvert the indigenous knowledge system. Therefore, a Motswana reader would find that the text expresses ambiguities between his or her tradition and the written tradition. Firstly, in verses 20-21, by referring to Badimo [devils], Moffat creates a dispute within the psyche of a Motswana. Secondly, the text becomes a tool for transferring the Western worldview through the Western colonial Christian religion as a discursive instrument to undermine ngwao ya Batswana [tradition or customs]. Lastly, the practices that have kept people together become immaterial and doubtful. Through the appropriation of the concept of heathenism and practices associated with Badimo in his translation, Moffat puts forward two world orders, namely the Western colonial Christian order and the Batswana religious world. He thus eliminates and implicitly condemns belief in the ancestors and replaces it with a new world order of Christian religion. 1 Corinthians 10:20-21 points to the politics of erasure.

\section{The reception of the Bible and effects on the Batswana}

The letters to Mahoko a Becwana point to this paradox experienced by the letter writers. Readers refer in their letters 
to debates relating to the relevance and significance of the belief system of the Batswana. It is in these debates that we observe the discourse about the Moffat Bible. They further indicate the interpretative interest in and the subversion of the Batswana world order. For the purposes of this article I will focus on only one letter.

Issue number 59 (December 1889), 29 Kuruman, 13 November 1889 Thelesho Magonaring of the Batlhware wrote the following letter:

\section{To the Editor,}

I am asking; I want to hear with understanding. Tell me that I might understand when to abstain from eating the cattle for male and female initiation participants because it is said they are sacrificial offerings. It is said that a believer is not supposed to eat them. But things from rain produced by rainmakers and traditional medicine, we eat them. We buy sorghum that has been grown with rain from rainmakers, and we even eat things from traditional healers and but the cattle of traditional healers. But you know we don't agree with those practices, and you know we say those things are just useless fabrications. So I say, which should we reject and which should we eat? Are not these all things that we despise as Christians - I mean female and male initiation rites, traditional medicine and rainmaking - and is it we who consume guinea fowl soup but claim not to eat its meat?

I am, Thelesho Maganaring, of the Batlhware. (Mgadla \& Volz 2006:127)

The above letter, I would argue, draws attention to the effects of the translated biblical text as disruption, marginalisation, replacement, subversion and colonisation of the writer's spiritual spaces. This is represented by a disjuncture between spiritual spaces (i.e. occupied by belief in the role of the ancestors in the life of the people) and their active role in the divine realm. Ancestral practices and the prohibition on taking food offered to 'idols' are mentioned in 1 Corinthians 10:14-33. Furthermore, we also see the demonisation of ngwao ya Setswana [Setswana tradition and customs], or rather the core that makes the Batswana who they are. I would also argue that the letter reveals the dilemma experienced by the 'converted' Batswana. One cannot but wonder how such teachings might have affected the families of those who had 'converted' to the new religion. The letter also hints at the departure from what the missionaries viewed as an 'uncivilised', 'heathen' and 'barbaric' way of life in favour of an identity as a 'civilised' person and a 'believer' and shows the separation between those considered to be in 'darkness' and those in the 'light' of Christ.

\section{Conclusion}

African biblical scholars, particularly those taking their points of departure from decolonial and post-colonial translation theories, have argued that the Christian corpus of literature produced during the 'evangelisation' of the 'heathen' is a colonial product. Therefore, there has been a movement to decolonise these texts. The reception of Christianity among the Batswana was not an innocent exercise. The translation of the Bible into Setswana was aimed at eroding the Setswana belief system.

I have not attempted in this article to do an exegesis but rather to make an ideological criticism of 1 Corinthians 10:20-21 of the 1840 English-Setswana New Testament translated by Robert Moffat. In this article I have argued that the transmogrification of Badimo(ni) as suggesting devils was an act of altering the meaning and of morphing Badimo as a concept that has a specific cosmological meaning for the Batswana. This illustrates the beginnings of dehumanising non-European cultures and traditions. I have also argued that in translating devils as Badimo in 1 Corinthians 10:20-21, Moffat transformed this piece of scripture into a discursive tool to perform a culture-specific function, namely, to transfer imperialist cultural memory and standards to the Batswana readership.

I further argued that the vernacularisation of the Bible into Setswana was also not an innocent exercise. 1 Corinthians 10:20-21 serves as an example of the effects of vernacularisation, foreignisation and redomestication of certain concepts; hence, this was an attempt to supress the belief system of the Batswana. The letters to the Mahoko a Becwana point to the effects of the vernacularisation, foreignisation and redomestication of the Bible into Setswana. I have argued that it is in these letters that we are confronted with the dichotomy between being a Christian and abandoning tradition. The letters also point to the alteration and the morphing of ancestors into something charged with negativity. It is in the transmogrification of Badimo in 1 Corinthians 10:20-21 that the process of dehumanising Badimo as an evil 'heathenism' practice as expressed in the above letter is evident. Moffat's translation of the English Bible into Setswana was an act of hybridisation and creolisation. This happens through the reordering of Batswana cosmology and culture. Hence, this act was not a counterbalance against Setswana religious practices, but rather it corrupted the spirituality and culture of the Batswana. In addition, 1 Corinthians 10:20-21 typifies cultural evangelism as the act of civilisation (Dachs 1972:652; 1975:72).

\section{Acknowledgements Competing interests}

The author declares that he or she has no financial or personal relationships which may have inappropriately influenced him or her in writing this article.

\section{References}

Arduini, S. \& Nergaard, S., 2011, 'Translation a new paradigm', Translation Transdisciplinary Journal Inaugural Issue, 8-15.

Bassnett, S. \& Lefevere, A., 1990, Translation, history and culture, Cassell, London.

Bassnett, S. \& Trivedi, H. (eds.), 1999, Postcolonial translation: Theory and practice, Routledge, New York.

Bibela ea Boitsepho ee Cutseng Kholagano e Kholugolu le e Nca, tse ri Hetolecoeng mo Puon ea Sechuana, translated by Robert Moffat,1857, British \& Foreign Bible Society, London.

Cheyfitz, E., 1991, The poetics of imperialism: Translation and colonization from the Tempest to Tarzan, Oxford University Press, Oxford. 
Coldham, G.E., 1966, A bibliography of scriptures in African languages, The British and Foreign Bible Society, London.

Comaroff, J. \& Comaroff, J., 1988, 'Through the looking-glass: Colonial encounters of the first kind', Journal of Historical Sociology 1(1), 8-32. https://doi.org/10.1111/ j.1467-6443.1988.tb00002.x

Dachs, A.J., 1972, 'Missionary imperialism: The case of Bechuanaland', Journal of African History 13, 647-658. https://doi.org/10.1017/\$0021853700011981

Dachs, A.J., 1975, Papers of John Mackenzie, Witwatersrand University Press, Johannesburg.

Dingwaney, N.A. \& Maier, C. (eds.), 1995, Between languages and cultures: Translation and cross-cultural Texts, University of Pittsburgh Press, Pittsburgh.

Du Bois, W.E.B., 1903, The souls of black folk, A.C. McClurg, Chicago, IL.

Dube, M.W., 2014, 'Translating ngaka: Robert Moffat rewriting an indigenous healer', Studia Historiae Ecclesiasticae 40(1), 157-172.

Gentzler, E., 2001, Contemporary translation theories, 2nd edn., Multilingual Matters, Clevedon.

Hermanson, E.A., 2002, 'A brief overview of Bible translation in South Africa', Acto Theologica Supplementum 2, 8-18.

Khalagano Ench ea Yesu Keresete, eo e leñ Moréna oa Rona le Morebiluki: e e hetolecoeñ mo puoñ ea Secuana, translated by Robert Moffat, 1840, British \& Foreign Bible Society, London.

Mbembe, A., 2014, The Johannesburg Workshop in Theory and Criticism (under the umbrella of WISER) and the Seminar in Experimental Critical Theory (UCHRI) joined forces to organize a two-week Workshop on Archives of the Non-Racial woined forces to organize a two-week Workshop on Archives
which took place in South Africa from June 29 to July 11, 2014.

Metzger, B.M., 2001, The Bible in translation: Ancient and English versions, Bake Academic, Grand Rapids, MI.

Mgadla, P.T. \& Volz, S.C., (Translators/compilers), 2006, Words of Batswana: Letters to Mahoko a Becwana 1883-1896, Van Riebeeck Society, Cape Town.

Moffat, J., 1885, The Lives of Robert and Mary Moffat: With Portraits and Maps, A C Armstrong \& Son, New York.

Moffat, R., 1842a, Missionary labours and scenes in Southern Africa, J. Snow, London.

Moffat, R., 1842b, Mr. Moffat and the Bechuanas of South Africa, Carlton \& Porter New York.

Moffat, R., 1863, Rivers of water in a dry place: An account of the introduction of Christianity into South Africa and of Mr. Moffat's missionary labours, Religious Tract Society, London.
Moffat, R. \& Moffat, M., 1951, Apprenticeship at Kuruman: Being the journals and letters of Robert and Mary Moffat, 1820-1828, edited by I. Schapera, Chatto and Windus, London.

Mojola, A.O., 2004, 'Postcolonial translation theory and the Swahili Bible', in G.L.O.R. York \& P.M. Renju (eds.), Bible translation and African languages, pp. 77-104, Acton, Nairobi, Kenya.

Mojola, A.O. \& Wendland, E., 2003, 'Scripture translation in the era of translation studies', in T. Wilt (ed.), Bible translation: Frames of reference, pp. 28-80, St Jerome, Northampton, MA.

Mothoagae, I.D., 2014, 'The gendered God in the Setswana Bible and the captivity of Modimo: Moffat and the translating of the Bible into Setswana', Studia Historiae Ecclesiasticae 40(2), 149-168.

Muller, K.O.E., 1958, Report on the translation of the Bible into Central Tswana during the Years 1929, 1939 and 1950 to 1958 by a Translating Commission, The British and Foreign Bible Society, Cape Town.

Ndlovu-Gatsheni, S.J., 2013, 'Why Decoloniality in the 21 century?' The Thinker 48 11-15, February, http://www.thethinker.co.za/resources/48\%20Thinker\%20 full $\% 20$ mag.pdf

Ntloedibe-Kuswani, G.S., 2000, 'Ngaka and Jesus as liberators: A comparative reading', in O. Gerald, G. West \& W. M. Dube (eds.), The Bible in Africa, pp. 498-510, Brill, Leiden.

Ntloedibe-Kuswani, G.S., 2001, 'Translating the divine: The case of Modimo in the Setswana Bible', in W.M. Dube (ed.), Other ways of reading African women and the Bible, pp. 78-97, Society of Biblical Literature, Atlanta, GA.

Pratt, M.L., 1985, 'Scratches on the face of the country: Or, what Mr. Barrow saw in the land of the Bushmen', Critical Inquiry 12, 119-143. https://doi.org/10.1086/448324

Quijano, A., 2000, 'Qué tal Raza!' Revista del CESLA [S.I.], n. 1, 192-200, Nov. 2000 viewed n.d., from http://www.revistadelcesla.com/index.php/revistadelcesla/ article/view/379

Rafael, V., 1988, Contracting colonialism: Translation and Christian conversion in Tagalog Society under Early Spanish Rule, Cornell University Press, Ithaca, NY.

Robinson, D., 1997, Translation and empire: Postcolonial theories explained, St. Jerome, New York.

Sheehan, J., 2005, The Enlightenment Bible: Translation, scholarship, culture, Princeton University Press, Princeton, NJ.

The King James Version, 1611, Samuel Bagster \& Sons, London, Logos Research Systems, Exported from Logos Bible Software, 10 March 2015.

Wynter, S., 2003, 'Unsettling the coloniality of being/power/truth/Freedom towards the human, 'Ufter man, its overrepresentation - An argument', The New Centennial Review 3(3), 257-337. https://doi.org/10.1353/ncr.2004.0015 